\title{
Covid-19: Hospitals can remove $15 \%$ cap on testing of NHS staff
}

\section{Gareth lacobucci}

The BMJ

NHS hospitals have been told to remove the $15 \%$ cap on the proportion of tests for covid-19 infection that they allocate to staff, as the government strives to get more staff who are currently isolating back to work as quickly as possible.

The move comes as the UK government faces mounting criticism over its inability to ramp up testing capacity quickly enough. As of 1 April the government said that there was capacity for testing 12750 people a day-a fraction of the number being tested in other countries, such as Germany, which is testing around 70000 people a day.

On Friday the UK government announced that it was opening three new labs specifically to process tests from NHS staff, ${ }^{1}$ but capacity is very limited, and medical leaders are frustrated by the lack of progress.

Chaand Nagpaul, BMA council chair, said, "It's been weeks since the government said they would make priority testing for healthcare workers happen, so the profession deserves this to become a reality now."

On 29 March NHS England bosses wrote to all NHS trusts, ${ }^{2}$ asking them to consider how they would prioritise staff for testing and advising them to start with those working in critical care, emergency departments, and ambulance services. Trusts were asked to allocate a maximum of $15 \%$ of their daily testing capacity to this purpose.

\section{Lab capacity}

But on 1 April NHS England wrote to hospitals to say that the cap was being removed as capacity increased. ${ }^{3}$ The letter said, "We want to max-out all available capacity ... and so are now removing the $15 \%$ cap immediately. Effective today we are therefore asking chief executives of trusts that host an NHS lab doing covid-19 testing personally to ensure that your lab's capacity is fully used each and every day."

Chris Hopson, chief executive of NHS Providers, which represents NHS trusts, said that he had seen preliminary data from staff who had been tested for covid-19 that suggested only a small proportion had the virus. This, he said, highlighted the importance of rolling out staff testing more widely.
He wrote on Twitter, "Intriguing data from a very small sample size ... only around $15 \%$ of those in 14 day isolation tested positive so other $85 \%$ could come back to work. If [this is] anything like right, a huge opportunity."

\section{Centralised testing}

On 31 March the cabinet office minister Michael Gove said that a global shortage of reagent chemicals was holding back efforts to ramp up capacity in the UK.

Hopson commented that trust leaders were reporting "major shortages of swabs and chemicals needed to complete tests" but that logistics were also an issue, with "some labs not working at full capacity [and] others struggling with high volumes." With the UK lagging way behind many other countries on testing, the UK's strategy of centralising covid-19 testing in a single large warehouse near Milton Keynes is among various policy decisions that are under scrutiny.

Quizzed on BBC Radio 4's Today programme on 1 April $^{5}$ as to why extra laboratory capacity in universities and in the private sector was not being used, the communities secretary, Robert Jenrick, insisted that the government was open to offers. "We want to work with any provider who can help us to ramp up production," he said.

Jenrick added that he expected the UK's overall testing capacity to reach 25000 "by the middle of April."

lacobucci G. Covid-19: healthcare staff in hotspot areas are prioritised as testing expands. BMJ 2020:368:m131810.1136/bmj.m1318

Pritchard A, Powis S, Marsh S-J. COVID-19 testing to support retention of NHS staff. NHS England and NHS Improvement. 29 Mar 2020. https://www.england.nhs.uk/ coronavirus/wp-content/uploads/sites/52/2020/03/covid-19-testing-and-staff-retentionletter-29-march-2020.pdt.

3 Philip P, Marsh S-J. Letter to chief executives of all NHS trusts and foundation trusts. NHS England and NHS Improvement. 1 Apr 2020. https://www.england.nhs.uk/coronavirus/ wp-content/uploads/sites/52/2020/03/covid-19-testing-letter-1-april-2020.pdf.

4 Hopson C. Thread by @ChrisCEOHopson: 1/22 Lots over the last 24 hours ... 1 Apr 2020. https://threadreaderapp.com/thread/1245231254397648902.html.

5 BBC Today Programme. 1 Apr 2020. https://www.bbc.co.uk/sounds/play/m000gskl.

Published by the BMJ Publishing Group Limited. For permission to use (where not already granted under a licence) please go to http://group.bmj.com/group/rights-licensing/ permissions 